CAMPBELL, C. A ética romântica e o espírito do consumismo moderno. Rio de Janeiro: Rocco, 2001.

\title{
O CONSUMO MODERNO COMO EXPERIÊNCIA ROMÂNTICA E ESTÉTICA, DA IMAGINAÇÃO À IMAGEM
}

\author{
Rosana Mauro ${ }^{1}$
}

O primeiro apontamento necessário para iniciar esta resenha é a atualidade e a possibilidade de adaptação em diferentes contextos de $A$ ética romântica e o espírito do consumismo moderno, de Colin Campbell, livro originalmente publicado na Inglaterra no final da década de 80 e traduzido para o Brasil no início dos anos 2000. Assistimos a uma atualização, é possível sugerir, da discussão trazida pelo autor, com o consumo cada vez mais estetizado e o aumento da produção de séries televisivas pelo mundo com os serviços de streaming, por exemplo.

Campbell argumenta que uma ética romântica foi fundamental para promover o espírito do consumismo moderno no século XVIII, na Inglaterra, época em que ocorreu uma revolução do consumidor marcada, entre outros elementos, pela ascensão de uma classe média, o consumo de luxo, o crescimento das horas dedicadas ao lazer, o culto ao romântico e a crescente procura por leitura de ficção.

A obra proporciona uma reflexão bastante intrigante e plausível, com o questionamento de antigas teorias do consumo, como a perspectiva "veblenesca", do estudioso Thorstein Veblen, baseada na noção de emulação social.

Segundo o autor, a classe média inglesa não apenas "imitava" a aristocracia, mas, muito pelo contrário, foi a responsável pela transformação do consumo moderno, justamente o estrato social mais carregado de valores protestantes, constituídos pela produção, poupança, trabalho e pela contraposição ao luxo e à ostentação da aristocracia.

Mas, o que de fato teria despertado o desejo pelo consumo nessa classe de valores puritanos? Campbell responde a essa pergunta com um percurso teórico que se inicia na ética protestante e seus novos aspectos negligenciados por Max Weber, passa por uma ética da sensibilidade e chega à ética romântica.

\footnotetext{
${ }^{1}$ Doutoranda em Ciências da Comunicação pela Universidade de São Paulo, USP. Mestre em Ciências da Comunicação pela Universidade de São Paulo, USP. E-mail: mauro.rosana@gmail.com
} 
O consumo moderno como experiência romântica e estética, da imaginação à imagem

de Rosana Mauro

De acordo com o autor, doutrinas posteriores à época mais forte do protestantismo inglês haveriam contestado a linha de pensamento puritana e trazido à tona um sentimentalismo cristão, o otimismo e a bondade natural do homem. Além disso, o próprio calvinista tradicional não era desprovido de emoção, pois trazia consigo a melancolia.

O fato é que as novas correntes protestantes influenciaram o calvinismo, que começou a ser reinterpretado de forma mais sentimental, de modo a privilegiar a emoção e o prazer dos sentimentos. A ética resultante dessa transformação, explica Campbell, é a da sensibilidade, qualificada pela benevolência, aptidão à empática, expressão emocional, pelo hedonismo emotivo, gosto e intuição.

Porém, a sensibilidade fora desacreditada por levar as pessoas a duvidarem da sinceridade daqueles que experimentavam tamanhos sentimentos, que poderiam ser acusados, inclusive, de puro egoísmo e dissimulação. Isso ocasionou o declínio da ética da sensibilidade.

Dentre as manifestações do sentimentalismo consideradas grosseiras estão o romance sentimental e o romance gótico, criticados, entre outros motivos, por causar em seus leitores, maioria de mulheres, certa dependência como as drogas, levando-os a uma "decadência emocional".

Com o declínio da sensibilidade, dá-se lugar ao romantismo, distinguido pela procura por sinceridade e posição contra o exagero e a hipocrisia. Os românticos, que tinham como maior expoente o boêmio, exibiam a rejeição da tradição e da convenção e a busca de ideais nobres. Dois acontecimentos sociais foram cruciais para dar fôlego ao romantismo - A Revolução Industrial e a Revolução Francesa, que contestaram a aristocracia como autoridade social, validando um comportamento romântico na busca por um mundo melhor.

O subjetivismo, a imaginação e o individualismo levavam o romantismo também para a egolatria e o narcisismo. Pois, a recusa do mundo como ele é não impulsionava o romântico para o exterior social e sim para o seu próprio eu, para a busca da arte como forma de alcançar a perfeição. Somente através da poesia e da imaginação o homem poderia se elevar desse mundo existente. Além disso, o boêmio, apesar de idealista, não rejeitava os prazeres mundanos, pelo contrário, se entregava a eles, como ocorria com a bebida alcoólica. 
O consumo moderno como experiência romântica e estética, da imaginação à imagem

de Rosana Mauro

Pode-se dizer que o espírito romântico da época possibilitou o compartilhamento de valores hedonistas, idealistas, criativos e imaginativos entre escritores, boêmios, poetas e seu público. Desse modo, o consumo moderno, que, de acordo com o autor, não possuía nada de materialista, pôde ser ainda mais estimulado pela relação entre ficção e devaneio.

Um ponto importante colocado por Campbell no livro é a diferença entre fantasiar e devanear. O devaneio está mais atrelado à realidade, na medida em que imagina possíveis acontecimentos de modo que estes sejam agradáveis. Já a fantasia pode trazer à mente imaginações irreais. Sendo assim, o devaneio se assemelha mais com a imaginação do hedonista moderno, visto que este sonha com possibilidades de felicidade.

Desse modo, o ato de desejar e ansiar se torna prazeroso. Ao sonhar e atribuir significações agradáveis ao objeto de desejo, o indivíduo adquire mais prazer do que com a aquisição de fato, que pode ser frustrante em comparação ao devaneio. Contemplar ilustrações de produtos e vitrines é parte dessa imaginação. Trata-se de um desfrute que pode ser estritamente estético, nas palavras do autor, proveniente do prazer imaginativo.

[...] muitos dos produtos culturais oferecidos à venda nas sociedades modernas são consumidos, de fato, por servirem de apoio à elaboração dos devaneios. Isso é mais claramente real quanto aos romances, mas também se aplica a quadros, a peças, discos e filmes, assim como a programas de rádio e televisão (Campbell 2001:135).

A citação acima reforça a hipótese inicial da resenha que confere atualidade à obra de Campbell. Assim, seguindo o exemplo do autor que nos provoca com seus questionamentos, fechamos este texto com uma pergunta, trazendo a possibilidade de estender suas teorias do consumo moderno à contemporaneidade. Afinal, qual é o sentido da infinidade de produtos midiáticos e publicitários com os quais contamos hoje - seus entrelaçamentos, estéticas e possibilidades - senão a materialização de um devaneio de prazer, um pedaço, em imagem, de nossa ilimitada e cada vez mais estimulada imaginação?

\section{REFERÊNCIAS BIBLIOGRÁFICAS}

CAMPBELL, C. A ética romântica e o espírito do consumismo moderno. Rio de Janeiro: Rocco, 2001. 
O consumo moderno como experiência romântica e estética, da imaginação à imagem

de Rosana Mauro

Artigo aprovado: 17/06/2016 